\title{
Characterization, bioactive compounds and antioxidant potential of three Brazilian fruits
}

\author{
Marina C. Pereira ${ }^{a}$, Rosana S. Steffens ${ }^{a}$, André Jablonski ${ }^{b}$, Plinho F. Hertz ${ }^{\text {a }}$, Alessandro de O. Rios ${ }^{\text {a }}$, \\ Márcia Vizzotto $^{c}$, Simone H. Flôres ${ }^{\mathrm{a}, *}$ \\ a Instituto de Ciência e Tecnologia de Alimentos, Universidade Federal do Rio Grande do Sul (UFRGS), Av. Bento Gonçalves, 9500, Prédio 43.212, Campus do Vale, \\ Porto Alegre, RS CEP 91501-970, Brazil \\ ${ }^{\mathrm{b}}$ Departamento de Engenharia de Minas, Universidade Federal do Rio Grande do Sul (UFRGS), Av. Bento Gonçalves, 9500, Prédio 74, Campus do Vale, Porto Alegre, \\ RS CEP 91501-970, Brazil \\ ${ }^{\mathrm{c}}$ Embrapa Clima Temperado, Rodovia BR 392, km 78, P.O. 403, Pelotas, RS CEP 96010-971, Brazil
}

\section{A R T I C L E I N F O}

\section{Article history:}

Received 31 October 2011

Received in revised form 4 June 2012

Accepted 31 July 2012

\section{Keywords:}

Native fruits

Brazil

Chemical composition

Antioxidant

Carotenoids

Biodiversity and nutrition

Food composition

Food analysis

\begin{abstract}
A B S T R A C T
With the objective of stimulating the cultivation and consumption of native Brazilian fruits, the physicochemical composition and antioxidant potential of three native species, namely the araticu-domato (Rollinia sylvatica A. St.-Hil.), pindo palm (Butia capitata (Mart.) Becc.) and mandacaru-de-trêsquinas (Cereus hildmannianus K. Schum.) were determined in this study. The pindo palm fruit stood out because of its elevated carotenoid content $(39.6 \mu \mathrm{g} / \mathrm{g})$ and greater antioxidant capacity $(26 \mu \mathrm{M}$ trolox $/ \mathrm{g}$ of fresh sample) by the ABTS (2,2-azino-bis-3-ethylbenzothiazoline-6-sulfonic) method, although by the DPPH (2,2-diphenyl-1-picrylhydrazyl) method, the pindo palm fruit (3847.5 g of fresh sample/g DPPH) and mandacaru-de-três-quinas fruit (3249.8 g of fresh sample/g DPPH) were considered to have the same antioxidant potential with no difference between them. The mandacaru-de-três-quinas fruit also showed the highest total phenolic compound content $(1337.3 \mathrm{mg} / 100 \mathrm{~g})$. Although the araticu-do-mato presented the highest vitamin $C$ content $(0.32 \mathrm{mg} / \mathrm{g})$, it did not differ statistically from the mandacaru-de-três-quinas fruit $(0.25 \mathrm{mg} / \mathrm{g})$; on the other hand, it was considered to be equal to the pindo palm fruit $(0.23 \mathrm{mg} / \mathrm{g})$. The araticu-do-mato also showed the best result for the TSS/TTA (total soluble solids/total titratable acidity) ratio (41.92), thus it was adequate for in natura consumption and for processing as well.
\end{abstract}

(c) 2012 Elsevier Inc. All rights reserved.

\section{Introduction}

Due to the incomplete efficiency of the human endogenous defense system, the influence of external factors such as smoking, pollution, UV radiation and food, as well as the existence of some physiopathological processes (aging, obesity, inflammation and ischemia), the importance of bioactive compounds obtained from diet has been well established, which can help overcome such deficiencies and also promote protection, prevention or reduction of the effects caused by oxidative stress (Pietta, 2000; Huang et al., 2005).

The association between a diet rich in fruits and vegetables and a decrease in the risk of cardiovascular diseases and certain types of cancer is based on epidemiological evidence and, by hypothesis,

\footnotetext{
* Corresponding author at: Instituto de Ciência e Tecnologia de Alimentos, Universidade Federal do Rio Grande do Sul, UFRGS, P.O. Box 15090, Porto Alegre, Rio Grande do Sul 91501-970, Brazil. Fax: +55 5133087048.

E-mail address: simone.flores@ufrgs.br (S.H. Flôres).
}

on their antioxidant contents (Alonso et al., 2004). The action of these antioxidant compounds is related to the attenuation of oxidative events that could contribute to the pathophysiology of these diseases (Pietta, 2000), and some vitamins, phenolic compounds and carotenoids stand out among them.

For instance, vitamin C captures oxygen radicals and the formed species following the loss of one electron act as free radicals, such as semidehydroascorbic acid or the ascorbyl radical. These species are relatively stable when compared to other free radicals, with half-lives of $10^{-5} \mathrm{~s}$ and are fairly unreactive (Padayatty et al., 2003). Moreover, they have the highest oxidizing power of recycling vitamin $\mathrm{E}$ in the lipid peroxidation process of membranes and lipoproteins (Murakami et al., 2006). The antioxidant effects of phenolic compounds are attributed to the reducing power of the aromatic hydroxyl group, which reduces reactive free radicals (Shahidi et al., 1992) and is capable of chelating transition metals. On the other hand, carotenoids protect biological systems from free radicals by transferring the energy of the excited oxygen molecule to the carotenoid molecule itself, reacting mainly with the peroxide radicals and molecular oxygen (Beutner et al., 2001). 
Brazil stands out in this context due to its elevated production of different native and exotic fruit trees as a result of its vast territorial extension and its insertion, mainly in tropical and temperate climate zones. However, despite the fact that agro-business is one of the most competitive sectors of the Brazilian economy (Brasil, 2009), large plantations that grow few species are taking over more area year by year, maintaining and increasing their productivity by means of fertilizers, herbicides and other chemicals. The population consequently loses the chance of varying their diet and knowing the use of native species capable of offering rich, nutritious alternatives, since there are innumerous economically under-explored species. Such species could be more widely used for in natura consumption or in the production of sweets, jams, juices and ice-creams.

Aiming to stimulate the cultivation and consumption of Brazilian native species, offering alternative foods that contribute to overall health, the current work determined the chemical composition, antioxidant potential, total phenolic compounds, vitamin $C$ content and the carotenoid profile of three native species from the south of Brazil.

\section{Materials and methods}

\subsection{Sample material}

The araticu-do-mato (Rollinia sylvatica A. St.-Hil.), pindo palm fruit (Butia capitata (Mart.) Becc.) and mandacaru-de-três-quinas (Cereus hildmannianus K. Schum.), were the fruits used in the study, which were obtained from the active germplasm bank of native fruit trees of Embrapa Temperate Climate Station (Pelotas/RS/ Brazil) with the exception of the mandacaru-de-três-quinas, which came from the city Barra do Ribeiro (RS/Brazil). The araticu-do mato is an evergreen tree 6-8 $\mathrm{m}$ with fruits of sincarpo bacaceo, sweet and juicy pulp containing with many seeds, pindo palm fruit is a palm around 4-5 $\mathrm{m}$ and fruit has fibro-juicy mesocarp (pulp), acid flavor and the mandacaru-de-três-quinas is an arborescent cactus with sweet white pulp, black seeds, soft and edible. The fruits were incorporated in the Institute of Natural Sciences (ICN) Herbarium (UFRGS) under the number of 89236, 34139 and 115413 for araticu-do-mato, pindo palm and mandacaru-de-três-quinas, respectively.

All samples were collected when fully mature, in 2 batches containing about $3 \mathrm{~kg}$ of fruits. The fruits of pindo palm were harvested between the months of February and March, araticudo-mato between April and May and mandacaru-de-três-quinas between March and May 2010. The fruits were pre-selected considering the absence of visible injury and infections, and also color and size uniformity were taken into account as well, afterwards they were stored frozen $\left(-20^{\circ} \mathrm{C}\right)$ until analyzed. In all the analysis, the normally edible parts of the fruits were used, that is, for the pindo palm fruit the skin and pulp were considered, but only the pulp for the araticu-do-mato and mandacaru-de-três-quinas. At the time of analysis, at least 10 fruits were thawed at room temperature and homogenized in an Ultra-turrax homogenizer (Ika, Artur Nogueira, São Paulo, Brazil) to determine the content of total soluble solids, total titratable acid, protein, sugars, ash, moisture, vitamin C, phenolic compounds and antioxidant activity. To analyze the content of lipids and fibers, the samples after homogenized, were freezedried (Apparatus Inc., EUA) and ground with a mortar and pestle. The results are expressed as fresh matter, except for proximate composition (proteins, lipids, carbohydrates, fiber) that was expressed as dry matter. All analyses were performed in triplicate and the results were expressed as mean and standard deviation.

\subsection{Chemical composition}

All analyses were carried out according to AOAC (1997). The protein concentration was determined by the Kjeldahl method using a conversion factor of 5.75. The lipid concentration was determined for Soxhlet extraction method, food fiber (total and insoluble) using the enzymatic-gravimetric method, the ash in muffle furnace controlled to $550{ }^{\circ} \mathrm{C}$, moisture contents determination by gravimetry, the total carbohydrate content was determined by difference, and the reducing and non-reducing sugars were determined by Eynon-Lane method. Total titratable acidity (TTA) was determined by titration and the total soluble solids (TSS) by using a digital PAL-3 refractometer (Atago Co., Taiwan, China).

\subsection{Total phenolic compounds}

To extract these substances, five grams of fresh sample were homogenized in an Ultra-turrax homogenizer with $20 \mathrm{~mL}$ methanol, and centrifuged for $20 \mathrm{~min}$ at $25,400 \times \mathrm{g}$ in a refrigerated centrifuge at $4{ }^{\circ} \mathrm{C}$. A $250 \mu \mathrm{L}$ aliquot of the supernatant was diluted in $4 \mathrm{~mL}$ of ultra-filtered water and a control was also prepared containing $250 \mu \mathrm{L}$ of methanol. The samples and the control were combined with $250 \mu \mathrm{L}$ of $0.25 \mathrm{~N}$ Folin-Ciocalteau Reagent (Swain and Hillis, 1959). After 3 min of reaction, $500 \mu \mathrm{L} 1 \mathrm{~N} \mathrm{Na}_{2} \mathrm{CO}_{3}$ were added, the mixtures incubated for $2 \mathrm{~h}$ at room temperature and the absorbance read at $725 \mathrm{~nm}$ in an Ultrospec model 3100 pro UVvisible spectrophotometer (Amersham Biosciences, Sweden). A standard curve was constructed to quantitate the phenolic compounds, using chlorogenic acid in the concentration range from 0 to $0.50 \mu \mathrm{g} / \mathrm{mL}$. The results were expressed in $\mathrm{mg}$ chlorogenic acid equivalents $/ 100 \mathrm{~g}$ fresh sample.

\subsection{Antioxidant activity}

Methodology based on sequestering the 2,2- diphenyl-1picrylhydrazyl (DPPH) radical was used to determine the antioxidant activity (Brand-Wiliams et al., 1995) and also the 2,2'-azinobis(3-ethylbenzthiazoline-6-sulphonic acid) (ABTS) method (Kuskoski et al., 2005). The extract was obtained from $5 \mathrm{~g}$ of sample ground in methanol (50\%) and acetone (70\%) sequentially, using three different dilutions (1:5(v/v), 1:10(v/v), 1:15(v/v)). The fresh samples were weighed in centrifuge tubes and extracted sequentially with $40 \mathrm{~mL}$ of methanol/water $(50: 50, \mathrm{v} / \mathrm{v})$ at room temperature for $1 \mathrm{~h}$. The tubes were centrifuged at $25,400 \times g$ for $15 \mathrm{~min}$ and the supernatant was recovered. Then $40 \mathrm{~mL}$ of acetone/ water $(70: 30, v / v)$ was added to the residue at room temperature, extracted for $60 \mathrm{~min}$ and centrifuged. Methanol and acetone extracts were combined, made up to $100 \mathrm{~mL}$ with distilled water and used to determine antioxidant capacity. For the DPPH method, a $0.1 \mathrm{~mL}$ aliquot of each dilution of the extract was reacted with $3.9 \mathrm{~mL}$ of DPPH radical $(0.06 \mathrm{mM})$. The readings were made in a spectrophotometer at $515 \mathrm{~nm}$ after $30 \mathrm{~min}$. The results were expressed in $g$ of fresh sample/g DPPH. For the ABTS method, a $30 \mu \mathrm{L}$ aliquot of each extract dilution was reacted with $3.0 \mathrm{~mL}$ of ABTS radical ( $5 \mathrm{~mL}$ ABTS stock solution with $88 \mu \mathrm{L}$ of solution of potassium persulfate) and the reading taken at $734 \mathrm{~nm}$ after $6 \mathrm{~min}$. The results were expressed as $\mu \mathrm{M}$ trolox/g fresh sample.

\subsection{Vitamin C}

The determination of vitamin C was based on the methodology proposed by Rosa et al. (2007) with some modifications. Each $5 \mathrm{~g}$ sample was ground in an Ultraturrax with $20 \mathrm{~mL} 0.05 \mathrm{M}$ suprapure 96\% sulfuric acid (Merck, Darmstadt, Germany) for $1 \mathrm{~min}$, centrifuged at $25,400 \times g$ for $15 \mathrm{~min}$ and then filtered through a Teflon hydrophilic filter unit. The analyses were carried out in a 
high performance liquid chromatography unit (Agillent, Waldbronn, Germany), equipped with a degasser, a quaternary solvent pump and a UV/Vis detector. The column used was a $250 \mathrm{~mm} \times 4.6 \mathrm{~mm}$ i.d., $5 \mu \mathrm{m}, \mathrm{C}_{18}$ polymeric column (Vydac, Southborough, MA, USA). The mobile phase was $0.05 \mathrm{M}$ suprapure sulfuric acid at $1.0 \mathrm{~mL} / \mathrm{min}$, with an injection volume of $10 \mu \mathrm{L}$ and wavelength of $254 \mathrm{~nm}$. The vitamin $\mathrm{C}$ was quantitated using a standard curve constructed using ascorbic acid >95\% (Sigma, Japan) in a concentration range from 1 to $0.001 \mathrm{mg} / \mathrm{mL}$. The results were expressed as mg ascorbic acid/g fresh sample.

\subsection{Carotenoid profile}

The carotenoid extract was prepared according to Mercadante and Rodriguez-Amaya (1991). The main steps were the extraction of the pigments with acetone and saponification with $10 \% \mathrm{KOH}$ in methanol overnight at room temperature. After removing the alkali with deionized water the extract was concentrated in a rotary evaporator (Fisatom, Uberlândia, Minas Gerais, Brazil) $\left(T<35^{\circ} \mathrm{C}\right)$, dried in a nitrogen flow and stored in the freezer for subsequent quantitation by high performance liquid chromatography. The column used was a $250 \mathrm{~mm} \times 4.6 \mathrm{~mm}$ i.d., $3 \mu \mathrm{m}, \mathrm{C}_{30}$ reversed phase polymeric column (YMC, Japan). The mobile phase was water, methanol 99.99\% (J.T.Baker, Mexico) and tert-methyl butyl ether (MTBE) 99.96\% (J.T.Baker - Mallinckrodt, EUA) starting at 5:90:5 (v/v/v), reaching 0:95:5(v/v/v) in $12 \mathrm{~min}, 0: 89: 11(\mathrm{v} / \mathrm{v} / \mathrm{v})$ in $25 \mathrm{~min}, 0: 75: 25(\mathrm{v} / \mathrm{v} / \mathrm{v})$ in $40 \mathrm{~min}$ and finally 0:50:50 $(\mathrm{v} / \mathrm{v} / \mathrm{v})$ after a total of $60 \mathrm{~min}$, with a flow rate of $1 \mathrm{~mL} / \mathrm{min}$ at $33^{\circ} \mathrm{C}$ (Zanatta and Mercadante, 2007). For quantification, a standard curve was constructed with $\beta$-carotene $>93 \%$ (Sigma, USA) (5$50 \mu \mathrm{g} / \mathrm{mL}$ ), $\alpha$-carotene $>95 \%$ (Fluka, USA) $(2-25 \mu \mathrm{g} / \mathrm{mL}$ ), lutein $>95 \%$ (Indofine Chermical Company, Inc., England) (1-65 $\mu \mathrm{g} / \mathrm{mL}$ ), cryptoxanthin $>95 \%$ (Sigma, USA) $(4-100 \mu \mathrm{g} / \mathrm{mL}$ ) and zeaxanthin $>95 \%$ (Fluka, USA) $(1-40 \mu \mathrm{g} / \mathrm{mL}$ ). The limits of quantitation (LQ) and detection (LD) were, respectively, for $\beta$-carotene and 9 -cis- $\beta$ carotene: $10.89 \times 10^{-2} \mathrm{mg} / \mathrm{kg}, 6.53 \times 10^{-2} \mathrm{mg} / \mathrm{kg}$; for lutein: $1.15 \times 10^{-2} \mathrm{mg} / \mathrm{kg}, \quad 6.9 \times 10^{-3} \mathrm{mg} / \mathrm{kg} ; \quad$ for cryptoxanthin: $3.51 \times 10^{-2} \mathrm{mg} / \mathrm{kg}, \quad 2.11 \times 10^{-2} \mathrm{mg} / \mathrm{kg}$; for zeaxanthin: $1.59 \times 10^{-2} \mathrm{mg} / \mathrm{kg}, \quad 9.56 \times 10^{-2} \mathrm{mg} / \mathrm{kg} ; \quad$ for $\quad \alpha$-carotene: $3.28 \times 10^{-2} \mathrm{mg} / \mathrm{kg}, 1.97 \times 10^{-2} \mathrm{mg} / \mathrm{kg}$; for $\beta$-carotene 5,6 epoxide $7.43 \times 10^{-2} \mathrm{mg} / \mathrm{kg}, \quad 4.46 \times 10^{-2} \mathrm{mg} / \mathrm{kg}$; for 13 -cis- $\beta$-carotene: $7.43 \times 10^{-2} \mathrm{mg} / \mathrm{kg}, 4.46 \times 10^{-2} \mathrm{mg} / \mathrm{kg}$. The results were expressed as $(\mathrm{g} / \mathrm{g}$ fresh sample.

Qualification analysis was assured taking into consideration the following criteria: (1) elution order in reverse HPLC of each carotenoid standard in the established conditions of chromatographic analysis; (2) retention time based on the average of three different measurements of all the commercial standards comparing with the retention time of all the coincident peaks in the sample and in its duplicate; and (3) comparison with commercial standards acquired.

\subsection{Statistical analysis}

The results were analyzed by ANOVA and the Tukey means comparison test at a level of $5 \%$ of significance, using the Statistica 7.0 program.

\section{Results and discussion}

\subsection{Chemical composition}

It is noticeable from the results shown in Table 1 that the values for proximate composition of the three fruits were significantly different, with the exception of dietary fiber, for which the araticudo-mato and mandacaru-de-três-quinas presented values considered to be equal and, on average, 1.78 times higher than those for the pindo palm fruit.

The values for araticu-do-mato and mandacaru-de-três-quinas were within the range of fiber contents found for other species of their botanical families, such as atemoya (Annona atemoya Mabb) (7.7 g/100 g) and sugar apple (Annona squamosa L.) (13.6 g/100 g) (NEPA/UNICAMP, 2006) from the Annonaceae family, and Opuntia dillenii (Ker Gawl.) Haw. (5.71 g/100 g) and Opuntia ficus indica Mill. (9.49 g/100 g) from the Cactaceae family (Medina et al., 2007). It should also be mentioned that various traditionally consumed fruits present similar fiber contents, such as Fuji apples $(8.2 \mathrm{~g} /$ $100 \mathrm{~g})$, mangoes $(8.14 \mathrm{~g} / 100 \mathrm{~g})$, Japanese tangerines $(8.3 \mathrm{~g} / 100 \mathrm{~g})$ and dwarf papayas ( $8.77 \mathrm{~g} / 100 \mathrm{~g}$ ) (NEPA/UNICAMP, 2006).

On the other hand the pindo palm fruit demonstrated higher moisture and protein contents, the latter component being three times greater than the araticu-do-mato. The protein content of the pindo palm fruit is comparable to what is found in popular fruits such as plums $(5.26 \mathrm{~g} / 100 \mathrm{~g})$, nanica bananas $(5.78 \mathrm{~g} / 100 \mathrm{~g})$, jack fruit $(5.62 \mathrm{~g} / 100 \mathrm{~g})$ and morcot-type tangerines $(5.52 \mathrm{~g} / 100 \mathrm{~g}$ ) (NEPA/UNICAMP, 2006).

Furthermore the araticu-do-mato stood out for having higher ash values almost 5 times the value found in the pindo palm fruit and more than twice found in the mandacaru-de-três-quinas. The same occurred for the carbohydrates, where this fruit surpassed the values found in the pindo palm fruit and the mandacaru-detrês-quinas by 1.69 and 1.38 times, respectively. The carbohydrate content of the araticu-do-mato can be compared with fruits such as the cocoa fruit (19.4 g/100 g), chocolate persimmon (19.3 g/100 g), jack fruit (22.5 g/100 g) and pacova banana (20.3 g/100 g) (NEPA/ UNICAMP, 2006). Other annonaceae species also show high carbohydrate contents such as the sugar apple (A. squamosa L. $19 \mathrm{~g} / 100 \mathrm{~g}$ ) and atemoya (A. atemoya Mabb - $23.3 \mathrm{~g} / 100 \mathrm{~g}$ ) (NEPA/ UNICAMP, 2006). However these fruits displayed higher protein and lipid contents than the araticu-do-mato studied in the present work.

In addition, the mandacaru-de-três-quinas presented a higher lipid content, almost 7 and 15 times higher than the values found for the pindo palm fruit and araticu-do-mato, respectively. However another Cactaceae fruit obtained from the forage palm (O. ficus-indica Mill.), showed a much lower lipid content $(0.50 \mathrm{~g} /$ $100 \mathrm{~g}$ ) (Medina et al., 2007). It is worth remembering that different results, even for fruits of the same species, are attributed to various factors such as: analytical methodology, cultivar, soil-climatic conditions, cultivation method, fruit maturity and storage conditions.

The physicochemical characteristics related to flavor represent important quality attributes for the commercialization and use of the fruit in elaborating industrial products. It is noticeable in Table 2 that the fruits presented statistical differences between the three fruits for TSS, TTA and the TSS/TTA ratio.

Among the fruits examined, the araticu-do-mato regarding the TSS content, presented twice the value of the mandacaru-de-trêsquinas, which had the lowest content of the three species analyzed, presenting values below those in other studies on the same species 14.58-40 Brix (Medina et al., 2007; Cerezal and Duarte, 2005). These divergences could be attributed to differences in the cultivars and climatic variations in the year the fruits were harvested.

Another important attribute in the determination of fruit quality, apart from the total soluble solids, is the total titratable acidity. The pindo palm fruit presented three times more acid than the araticu-do-mato and almost six times more than the mandacaru-de-três-quinas. The high values for acidity could influence the flavor of the product, but they also help conserve the pulp for longer storage periods, since acid products have a reduced probability for microbial contamination. The 
Table 1

Proximate composition of fruits from native species to Rio Grande do Sul State/Brazil.

\begin{tabular}{|c|c|c|c|}
\hline \multirow[t]{2}{*}{ Proximate composition } & \multicolumn{3}{|l|}{ Fruits } \\
\hline & Araticu-do-mato & Pindo palm fruit & Mandacaru-de-três-quinas \\
\hline Moisture & $78.61 \pm 0.41^{c}$ & $87.82 \pm 0.08^{\mathrm{a}}$ & $83.72 \pm 0.01^{\mathrm{b}}$ \\
\hline Ash & $1.18 \pm 0.006^{\mathrm{a}}$ & $0.25 \pm 0.01^{\mathrm{c}}$ & $0.56 \pm 0.03^{b}$ \\
\hline $\mathrm{TDF}^{\mathrm{A}}$ & $8.74 \pm 0.32^{\mathrm{a}}$ & $4.89 \pm 0.04^{\mathrm{b}}$ & $8.7 \pm 0.27^{\mathrm{a}}$ \\
\hline $\mathrm{IDF}^{\mathrm{B}}$ & $7.99 \pm 0.23^{\mathrm{a}}$ & $4.08 \pm 0.005^{c}$ & $8.7 \pm 0.26^{a}$ \\
\hline Protein & $1.82 \pm 0.03^{\mathrm{c}}$ & $5.79 \pm 0.09^{\mathrm{a}}$ & $4.05 \pm 0.09^{\mathrm{b}}$ \\
\hline Lipids & $0.28 \pm 0.07^{\mathrm{c}}$ & $0.61 \pm 0.02^{\mathrm{b}}$ & $4.34 \pm 0.05^{\mathrm{a}}$ \\
\hline Carbohydrates & $17.89 \pm 0.28^{\mathrm{a}}$ & $10.55 \pm 0.06^{\mathrm{c}}$ & $12.93 \pm 0.11^{\mathrm{b}}$ \\
\hline Total sugars & $8.84 \pm 0.1^{\mathrm{a}}$ & $4.18 \pm 0.04^{\mathrm{b}}$ & $2.06 \pm 0.04^{\mathrm{c}}$ \\
\hline Reducing sugars & $7.82 \pm 0.03^{\mathrm{a}}$ & $1.8 \pm 0.07^{\mathrm{b}}$ & $1.92 \pm 0.12^{\mathrm{b}}$ \\
\hline
\end{tabular}

Values expressed as the mean \pm standard deviation of the mean. The same letter in the same line indicates no significant difference at the level of $5 \%$ significance.

A TDF, total dietary fiber.

B IDF, insoluble dietary fiber.

araticu-do-mato showed an intermediate value for acidity $(0.39 \%)$ as compared to the other two fruits. Several authors found low values for the acidity of other Cactaceas, with values varying from 0.078 to $0.33 \%$ citric acid (Medina et al., 2007; Cerezal and Duarte, 2005).

The TSS/TTA ratio provides a better evaluation of fruit flavor, being more representative than isolated measurements of the sugar contents or acidity. Thus the araticu-do-mato seems to have the best balance between sweet and acid, ensuring a pleasant flavor and being the most attractive among the species analyzed. On the other hand, despite showing a low TSS content, the mandacaru-de-trêsquinas also presented low acidity, resulting in a high TSS/TTA ratio, indicating a very sweet and tasty fruit. As a counterpart the pindo palm fruit had the lowest value for this parameter (TSS/TTA), presenting limitations for in natura consumption nevertheless, it still presents considerable potential for the agro-industries.

\subsection{Total phenolic compounds}

With respect to the total phenolic compound contents, the mandacaru-de-três-quinas showed a significantly greater amount, corresponding to twice that found in the araticu-do-mato and pindo palm fruit, the latter two being considered statistically equal (Table 3). In addition the mandacaru-de-três-quinas stood out when compared to blueberry (263-930 mg/100 g) (Sellapan et al., 2002), known worldwide for its beneficial properties in what concerns the human health.

\subsection{Antioxidant activity}

Table 3 also shows the results for antioxidant activity. Using the ABTS method there was a significant difference between the fruits, with the pindo palm fruit demonstrating the highest values, representing 6.74 times the value obtained for the araticu-do-mato and 1.32 times the value obtained for the mandacaru-de-trêsquinas. However for the DPPH method the values obtained for the pindo palm and mandacaru-de-três-quinas fruits were considered

Table 2

Total soluble solids (TSS) and total titratable acidity (TTA) in fruits from native species to Rio Grande do Sul State/Brazil.

\begin{tabular}{llll}
\hline Analyses & Fresh fruits & & \\
\cline { 2 - 4 } & Araticu-do-mato & Pindo palm fruit & $\begin{array}{l}\text { Mandacaru-de- } \\
\text { três-quinas }\end{array}$ \\
\hline TSS ( ${ }^{\circ}$ Brix) & $16.35 \pm 0.0^{\mathrm{a}}$ & $10.32 \pm 0.0^{\mathrm{b}}$ & $8.13 \pm 0.15^{\mathrm{c}}$ \\
TTA (\% citric acid) & $0.39 \pm 0.02^{\mathrm{b}}$ & $1.38 \pm 0.01^{\mathrm{a}}$ & $0.24 \pm 0.01^{\mathrm{c}}$ \\
TSS/TTA & $41.92^{\mathrm{a}}$ & $7.48^{\mathrm{c}}$ & $33.87^{\mathrm{b}}$ \\
\hline
\end{tabular}

Values expressed as the mean \pm the standard deviation of the mean. The same letters in the same line indicates no significant difference at the $5 \%$ level of significance. to be statistically equal and on average four times the value found in the araticu-do-mato.

The pindo palm fruit can also be compared with some plum varieties (17-20 $\mu \mathrm{M}$ trolox/g) (Walkowiak-Tomczak et al., 2008). However it displays less free radical sequestering capacity than in camu-camu $(153 \mu \mathrm{M}$ of trolox/g fruit $-478 \mathrm{~g}$ fruit/g DPPH), West Indian cherry $(96.6 \mu \mathrm{M}$ of trolox/g fruit $670 \mathrm{~g}$ fruit/g DPPH) and puçá-preto $(125 \mu \mathrm{M}$ of trolox/g fruit $414 \mathrm{~g}$ fruit/g DPPH) (Rufino et al., 2010). On the other hand, the mandacaru-de-três-quinas can be compared with uvaia $(18 \mu \mathrm{M}$ trolox $/ g$ fruit - $3247 \mathrm{~g} / \mathrm{g}$ DPPH) (Rufino et al., 2010). The antioxidant powers of the pindo palm fruit and the mandacarude-três-quinas was higher than in several other fruits, such as ace grapes $(9.2 \mu \mathrm{M}$ trolox/g), guava $(8.2 \mu \mathrm{M}$ trolox $/ \mathrm{g})$, cherimoya (4.8 $\mu \mathrm{M}$ trolox $/ g$ ) (Kuskoski et al., 2005), yellow mombim (7.8 $\mu \mathrm{M}$ of trolox/g fruit - $9397 \mathrm{~g}$ fruit/g DPPH), carnaúba $(10.7 \mu \mathrm{M}$ of trolox/g fruit - $3549 \mathrm{~g}$ fruit/g DPPH) and $u m b u$ (6.3 $\mu \mathrm{M}$ of trolox/g fruit - $7074 \mathrm{~g}$ fruit/g DPPH) (Rufino et al., 2010). Although the araticu-do-mato shows less antioxidant capacity than the other two fruits analyzed, it is still higher than cupuaçu (1.70-2 $\mu \mathrm{M}$ trolox/g) (Kuskoski et al., 2005).

\subsection{Vitamin $C$}

The vitamin $C$ concentration did not vary much between the fruits evaluated (Table 3 ), however the araticu-do-mato presented the highest value for this compound, without differing from the mandacaru-de-três-quinas statistically, and it also surpassed the value found in the pindo palm fruit significantly. The mandacarude-três-quinas showed an intermediate value, being considered statistically equal to the other two fruits.

Valente et al. (2011), on studying an araticu-do-mato species ( $A$. squamosa L.) native to the Brazilian savanna, they found lower

Table 3

Total phenolic compounds (TPC), antioxidant activity (DPPH and ABST methods) and vitamin C (Vit C) content in fruits from native species to Rio Grande do Sul State/ Brazil.

\begin{tabular}{lccc}
\hline Analyses & Fresh fruits & & \\
\cline { 2 - 4 } & Araticu-do-mato & Pindo palm fruit & $\begin{array}{l}\text { Mandacaru-de- } \\
\text { três-quinas }\end{array}$ \\
\hline TPC $^{\mathrm{A}}$ & $531.70 \pm 48.36^{\mathrm{b}}$ & $636.95 \pm 30.9^{\mathrm{b}}$ & $1337.28 \pm 58.05^{\mathrm{a}}$ \\
$\mathrm{ABTS}^{\mathrm{B}}$ & $3.85 \pm 0.04^{\mathrm{c}}$ & $25.96 \pm 0.07^{\mathrm{a}}$ & $19.61 \pm 0.75^{\mathrm{b}}$ \\
$\mathrm{DPPH}^{\mathrm{C}}$ & $15,946.52 \pm 161.22^{\mathrm{c}}$ & $3847.54 \pm 468.28^{\mathrm{a}}$ & $3249.77 \pm 158.57^{\mathrm{a}}$ \\
Vit C $^{\mathrm{D}}$ & $0.32 \pm 0.04^{\mathrm{a}}$ & $0.32 \pm 0.04^{\mathrm{a}}$ & $0.25 \pm 0.03^{\mathrm{ab}}$ \\
\hline
\end{tabular}

The values are expressed as the mean \pm the standard deviation of the mean. The same letters in the same line indicate no significant difference at the $5 \%$ level of significance.

A Expressed as mg chlorogenic acid equivalents/100 g fresh sample.

${ }_{B}$ Expressed as ( $M$ trolox equivalents/g fresh sample.

C Expressed as g fresh sample/g DPPH.

D Expressed as mg ascorbic acid/g fruit. 
Table 4

Carotenoid composition $(\mu \mathrm{g} / \mathrm{g})$ in fruits from native species to Rio Grande do Sul/Brazil.

\begin{tabular}{|c|c|c|c|c|c|}
\hline \multirow[t]{2}{*}{ No. peak } & \multirow[t]{2}{*}{ Carotenoids } & \multirow[t]{2}{*}{$\mathrm{RT}$ range (min) } & \multicolumn{3}{|c|}{ Concentration ( $\mu \mathrm{g} / \mathrm{g}$ fresh fruit) } \\
\hline & & & Araticu-do-mato & Pindo palm fruit & Mandacaru-de-três-quinas \\
\hline 1 & Lutein & 18 & $0.19 \pm 0.02^{\mathrm{b}}$ & $4.68 \pm 0.51^{\mathrm{a}}$ & $0.55 \pm 0.15^{\mathrm{b}}$ \\
\hline 2 & Zeaxanthin & 21 & $0.0019 \pm 0.001^{\mathrm{b}}$ & $0.099 \pm 0.01^{\mathrm{a}}$ & $0.019 \pm 0.001^{\mathrm{b}}$ \\
\hline 3 & 5,6-Epoxy- $\beta$-carotene & $29-30$ & $\mathrm{Nd}^{\mathrm{A}}$ & $0.92 \pm 0.11$ & $\mathrm{Nd}$ \\
\hline 4 & Cryptoxanthin & 32 & $0.0018 \pm 0.0001^{\mathrm{b}}$ & $0.24 \pm 0.03^{\mathrm{a}}$ & $0.011 \pm 0.001^{\mathrm{b}}$ \\
\hline 5 & 13-cis- $\beta$-Carotene & $34-35$ & Nd & $1.99 \pm 0.19$ & $\mathrm{Nd}$ \\
\hline 6 & $\alpha$-Carotene & 38 & $0.18 \pm 0.002^{\mathrm{a}}$ & $\mathrm{Nd}$ & $0.18 \pm 0.007^{\mathrm{a}}$ \\
\hline 7 & $\beta$-Carotene & $42-43$ & $0.065 \pm 0.003^{\mathrm{b}}$ & $21.67 \pm 3.07^{\mathrm{a}}$ & $0.086 \pm 0.004^{\mathrm{b}}$ \\
\hline \multirow[t]{2}{*}{8} & 9-cis- $\beta$-Carotene & 44 & $0.047 \pm 0.0001^{\mathrm{b}}$ & $10.17 \pm 0.74^{\mathrm{a}}$ & $0.048 \pm 0.001^{b}$ \\
\hline & Total & & $0.48 \pm 0.03^{b}$ & $39.77 \pm 4.16^{\mathrm{a}}$ & $0.89 \pm 0.16^{\mathrm{b}}$ \\
\hline
\end{tabular}

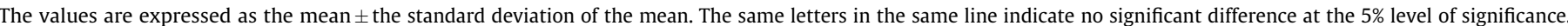
A $\mathrm{Nd}$, not detected.

vitamin $C$ concentrations $(0.029 \mathrm{mg} / \mathrm{g})$ than the ones found in the present study. Fruits such as passion fruit $(0.36 \mathrm{mg} / \mathrm{g})$ (Valente et al., 2011) and puçá-preto (0.29 $\mathrm{mg} / \mathrm{g}$ ) (Rufino et al., 2010) showed comparable amounts in araticu-do-mato and pindo palm fruit. The mandacaru-de-três-quinas had lower vitamin C concentration than what was found by Medina et al. (2007) for O. ficus indica Mill. (0.17 mg/g) and higher values for O. dillenii (Ker Gawl.) Haw. $(0.30 \mathrm{mg} / \mathrm{g})$, on characterizing two species from the genus Opuntia. Fruits such as banana $(0.0014 \mathrm{mg} / \mathrm{g})$, carambola (0.027 mg/g) (Valente et al., 2011), bacuri $(0.024 \mathrm{mg} / \mathrm{g}$ ) (Rufino et al., 2010) present lower values than the mandacaru-de-trêsquinas, whereas the Indian fig $(0.21 \mathrm{mg} / \mathrm{g})$, lime cultivar Tahiti $(0.21 \mathrm{mg} / \mathrm{g})$, tamarillo $(0.20 \mathrm{mg} / \mathrm{g})$ (Valente et al., 2011), cajá (0.26 mg/g), gurguri $(0.27 \mathrm{mg} / \mathrm{g})$ e umbu $(0.18 \mathrm{mg} / \mathrm{g})$ (Rufino et al., 2010) shows a comparable vitamin $C$ content.

\subsection{Carotenoid profile}

Among the native species analyzed, the pindo palm fruit presented significantly higher contents for all the carotenoids evaluated with the exception of $\alpha$-carotene, which was not identified in this fruit. The total carotenoid content found in the pindo palm fruit corresponded to 82.85 and 44.68 times the values found in the araticu-do-mato and mandacaru-de-três-quinas, respectively. Table 4 shows the carotenoid composition of the three fruits analyzed.

With respect to the araticu-do-mato and mandacaru-de-trêsquinas, these did not show the presence of 5,6-epoxy- $\beta$-carotene or 13 -cis- $\beta$-carotene, and for all the other carotenoids found, they presented low amounts which were considered statistically equal. Considering the total carotenoid contents for these fruits, lutein represented $39.6 \%$ for the araticu-do-mato $(0.55 \mu \mathrm{g} / \mathrm{g})$ and $61.8 \%$ for the mandacaru-de-três-quinas $(0.19 \mu \mathrm{g} / \mathrm{g})$ and was thus the major carotenoid of these fruits. Green leafy vegetables are generally known as sources of lutein, principally the dark green leaves such as spinach $(52-68 \mu \mathrm{g} / \mathrm{g}$ ) (Azevedo-Meleiro and Rodriguez-Amaya, 2005a) kale (44-52 $\mu \mathrm{g} / \mathrm{g}$ ) (Azevedo-Meleiro and Rodriguez-Amaya, 2005b), watercress (68 $\mu \mathrm{g} / \mathrm{g}$ ) and rocket $(50 \mu \mathrm{g} / \mathrm{g}$ ) (Kimura and Rodriguez-Amaya, 2003). However this carotenoid can be found in smaller amounts in fruits, in amounts similar to those found in the araticu-do-mato and mandacaru-detrês-quinas, such as in orange (0.1-0.2 $\mu \mathrm{g} / \mathrm{g}$ ) (Pupin et al., 1999). However, the two fruits examined here showed lower values when compared to the camu-camu $(3.8 \mu \mathrm{g} / \mathrm{g}$ ) (Zanatta and Mercadante, 2007), which also has lutein as the principal carotenoid. Of the main benefits associated with lutein, apart from evidence of a reduction in the risk of developing macular degeneration in old age, protective effects against atherosclerosis, cataract, cancer and damage caused by UV radiation stand out among other diseases (Marinova and Ribarova, 2007).
For the pindo palm fruit $\beta$-carotene $(21.67 \mu \mathrm{g} / \mathrm{g})$ outranked, representing more than $50 \%$ of the total content $(39.77 \mu \mathrm{g} / \mathrm{g})$. In addition the presence of the $\beta$-carotene isomer 9 -cis- $\beta$-carotene in considerable amounts $(10.17 \mu \mathrm{g} / \mathrm{g})$ representing $25.6 \%$ should be mentioned, and also lutein, which was present in smaller amounts, representing $11.8 \%$. The $\beta$-carotene concentration found in the pindo palm fruit was comparable to other fruits, such as the West Indian cherry (4-26 $\mu \mathrm{g} / \mathrm{g}$ ) (Porcu and Rodriguez-Amaya, 2006) and also in some vegetables such as lettuce $(9.9-25 \mu \mathrm{g} / \mathrm{g}$ ) (Kimura and Rodriguez-Amaya, 2003) and broccolis (16-19 $\mu \mathrm{g} / \mathrm{g}$ ) (De Sá and Rodriguez-Amaya, 2003). However when compared to tucuma (99 $\mu \mathrm{g} / \mathrm{g})$ (Rodriguez-Amaya, 1999), a palm tree considered rich source of $\beta$-carotene, the pindo palm fruit showed a much lower value. $\beta$-Carotene is considered the carotenoid with the greatest vitamin A potential, with $100 \%$ activity, besides that, it is the most efficient in sequestering free radicals after lycopene, acting in the prevention of chronic-degenerative diseases such as heart disease and cancer (Böhm et al., 2002).

\section{Conclusions}

The results obtained for the proximate composition of the native Brazilian fruits did not show much variation, and can be compared with the values found in various conventional fruits. However, with respect to their functional properties, the pindo palm and mandacaru-de-três-quinas fruits stood out due to their higher antioxidant capacities when compared to other traditionally consumed fruit species. Yet it seems that for the pindo palm fruit this potential is influenced by the carotenoid content, whereas for the mandacaru-de-três-quinas fruit can be attributed to the phenolic compound content, since they present high contents of these constituents. In addition, the mandacaru-de-trêsquinas together with the araticu-do-mato showed the highest vitamin C content, with amounts similar to those found in some citric fruits. The araticu-do-mato also had the best TSS/TTA ratio, indicating that it is suitable for in natura consumption as well as for processing. Thus these fruits appear as an option to increase the Brazilian agricultural matrix, since they possess functional characteristics of impact in the prevention of countless diseases. Nevertheless in order for them to be introduced into the productive systems and offered on a commercial scale, information on this topic is necessary and must be exposed allowing the cultivation of these species.

\section{Acknowledgments}

The authors are grateful to the Brazilian Research Agency (Coordenação de Aperfeiçoamento de Pessoal de Nível Superior CAPES) for their financial support. 


\section{References}

Alonso, M.G., de Teresa, S.P., Buelga, C.S., Gonzalo, J.C.R., 2004. Evaluation of the antioxidant properties of fruits. Food Chemistry 84, 13-18.

AOAC Official Method, 1997. Official Methods of Analysis, 16th ed. AOAC International, Gaithersburg, MD.

Azevedo-Meleiro, C.H., Rodriguez-Amaya, D.B., 2005a. Carotenoids of endive and New Zealand spinach as affected by maturity, season and minimal processing. Journal of Food Composition and Analysis 18, 845-855.

Azevedo-Meleiro, C.H., Rodriguez-Amaya, D.B., 2005b. Carotenoid composition of kale as influenced by maturity, season and minimal processing. Journal of the Science of Food and Agriculture 85, 591-597.

Beutner, S., Bloedorn, B., Frixel, S., Blanco, I.H., Hoffmann, T., Martin, H.-D., Mayer, B., Noack, P., Ruck, C., Schmidt, M., Schülke, I., Sell, S., Ernst, H., Haremza, S., Seybold, G., Sies, H., Stahl, W., Walsh, R., 2001. Quantitative assessment of antioxidant properties of natural colorants and phytochemicals: carotenoids, flavonoids, phenols and indigoids. The role of $\beta$-carotene in antioxidant functions. Journal of the Science of Food and Agriculture 81, 559-568.

Böhm, V., Pusptasari-Nienaber, N.L., Ferruzzi, M.G., Schwartz, S.J., 2002. Trolox equivalent antioxidant capacity of different geometrical isomers of $\alpha$-carotene, $\beta$-carotene, lycopene and zeaxanthin. Journal of Agricultural and Food Chemistry $50,221-226$.

Brand-Wiliams, W., Cuvelier, M.E., Berset, C., 1995. Use of a free radical method to evaluate antioxidant activity. Food Science and Technology 28, 25-30.

Brasil, 2009 Ministério da Agricultura, Pecuária e Abastecimento. Relatório de avaliação do plano plurianual 2008-2011. Secretaria Executiva Subsecretaria de Planejamento, Orçamento e Administração. Retrieved from: http://www. agricultura.gov.br/arq_editor/file/Ministerio/planos\%20e\%20programas/ relatorio_plurianual2008-2011.pdf (retrieved 2011)

Cerezal, P., Duarte, G., 2005. Utilización de cáscaras en la elaboración de productos concentrados de tuna (Opuntia ficus-indica (L.) Miller). Journal of the Professional Association for Cactus Development 7, 61-83.

De Sá, M.C., Rodriguez-Amaya, D.B., 2003. Carotenoid composition of cooked green vegetables from restaurants. Food Chemistry 83, 595-600.

Huang, D., OU, B., Prior, R.L., 2005. The chemistry behind antioxidant capacity assays. Journal of Agricultural and Food Chemistry 53, 1841-1856.

Kimura, M., Rodriguez-Amaya, D.B., 2003. Carotenoid composition of hydroponic leafy vegetables. Journal of Agricultural and Food Chemistry 51, 2603-2607.

Kuskoski, E.M., Asuero, A.G., Troncoso, A.M., Mancini-Filho, J., Fett, R., 2005. Aplicatíon de diversos métodos químicos para determinar actividad antioxidante en pulpa de frutos. Ciência e Tecnologia de Alimentos 25, 726-732.

Marinova, D., Ribarova, F., 2007. HPLC determination of carotenoids in Bulgarian berries. Journal of Food Composition and Analysis 20, 370-374.

Medina, E.M.D., Rodríguez, E.M.R., Romero, C.D., 2007. Chemical characterization of Opuntia dillenii and Opuntia ficus-indica fruits. Food Chemistry 103, 38-45.
Mercadante, A.Z., Rodriguez-Amaya, D.B., 1991. Carotenoid composition of a leafy vegetable in relation to some agricultural variables. Journal of Agricultural and Food Chemistry 39, 1094-1097.

Murakami, Y., Nagai, A., Kawakami, T., Hino, K., Kitase, A., Hara, Y., Okuda, M., Okita, K., Okita, M., 2006. Vitamin E and C supplementation prevents decrease of eicosapentaenoic acid in mononuclear cells in chronic hepatitis $\mathrm{C}$ patients during combination therapy of interferon $\alpha$-2b and ribavirin. Nutrition 22, 114-122.

NEPA/UNICAMP, 2006. Tabela brasileira de composição de alimentos - TACO. Versão 2.

Padayatty, S.J., Katz, A., Wang, Y., Eck, P., Kwon, O., Lee Je-Hyuk Chen, S., Corpe, C., Dutta, A., Dutta, S.K., Levine, M., 2003. Vitamin C as an antioxidant: evaluation of its role in disease prevention. Journal of the American College of Nutrition 22, 18-35.

Pietta, P.G., 2000. Flavonoids as antioxidants. Journal of Natural Products 63, 1035-1042.

Porcu, O., Rodriguez-Amaya, D.B., 2006. Variation in the carotenoid composition of acerola and its processed products. Journal of the Science of Food and Agriculture 86, 1916-1920.

Pupin, A.M., Dennis, M.J., Toledo, M.C.F., 1999. HPLC analysis of carotenoids in orange juice. Food Chemistry 64, 269-275.

Rodriguez-Amaya, D.B., 1999. A Guide to Carotenoid Analysis in Foods. International Life Sciences Institute (ILSI) Press, Washington, DC, p. 64.

Rosa, J.S., Godoy, R.L.O., Neto, O.J., Campos, R.S., Matta, V.M., Freire, C.A., Silva, A.S. Souza, R.S., 2007. Desenvolvimento de um método de análise de vitamina C em alimentos por cromatografia líquida de alta eficiência e exclusão iônica. Ciência e Tecnologia de Alimentos 27, 787-792.

Rufino, M.do.S.M., Alves, R.E., Brito, E.S., de Pérez-Jiménez, J., Saura-Calixto, F. Mancini-Filho, J., 2010. Bioactive compounds and antioxidant capacities of 18 non-traditional tropical fruits from Brazil. Food Chemistry 121, 996-1002.

Sellapan, S., Akoh, C.C., Krewer, G., 2002. Phenolic compounds and antioxidant capacity of Georgia-Grown blueberries and blackberries. Journal of Agricultural and Food Chemistry 50, 2432-2438.

Shahidi, F., Janitha, P.K., Wanasundara, P.D., 1992. Phenolic antioxidants. Food Science and Nutrition 32, 67-103.

Swain, T., Hillis, W.E., 1959. The phenolic constituents of Prunus domestica I. The quantitative analysis of phenolic constituents. Journal of the Science of Food and Agriculture 10,63-68.

Valente, A., Albuquerque, T.G., Sanches-Silva, A. Costa, E.S., 2011. Ascorbic acid content in exotic fruits: a contribution to produce quality data for food composition databases. Food Research International, http://dx.doi.org/ 10.1016/j.foodres.2011.02.012.

Walkowiak-Tomczak, D., Reguła, J., Łysiak, G., 2008. Phisico-chemical properties and antioxidant activity of selected plum cultivars fruit. ACTA Scientiarum Polonorum - Technologia Alimentaria 7, 15-22.

Zanatta, C.F., Mercadante, A.Z., 2007. Carotenoid composition from the Brazilian tropical fruit camu-camu (Myrciaria dubia). Food Chemistry 101, 1526-1532. 